\title{
20 BURIAL RIGHTS: PROTECTING THE RELIGIOUS AND CULTURAL HERITAGE OF COMMUNITIES IN SOUTH AFRICA
}

\section{Helena van Coller ${ }^{1}$}

\section{INTRODUCTION}

Over the years, cultural communities all over the world have experienced constant threats to their sacred sites, and religious and cultural communities in South Africa have experienced the same. Religious heritage sites and religious traditions play a significant role in educating future generations and creating a sense of belonging in communities. The phrase "burial rights" relates to the whole range of death and burial practices in respect of the deceased. The emphasis of this chapter will be in particular on burial places, both on public and private land. This is because among many cultures, a cemetery or burial site is often much more than just a place of final rest for the dead, but also a place of spiritual and cultural reference. In some cultures, particularly in African cultures, it is a place of connecting with ancestral spirits and for ancestral veneration. The chapter will first outline some of the legal mechanisms in place to protect and promote communities' religious rights and heritage espoused in the National Heritage Resources Act 25 of 1999 (NHRA), the South African Charter of Religious Rights and Freedoms (SACRRF), as well as the constitutional protection.

In relation to public land, the chapter will discuss some challenges faced by communities, particularly in relation to the reuse and relocation of graves. With reference to some practical examples, the chapter will highlight some inefficiencies not only with the legislation itself but also with the implementation thereof. A lack of consultation and engagement with stakeholders and a lack of coordination between the different tiers of government seems to be some of the biggest challenges. In relation to burying on private land, a conflict between the right to freedom of religion and property rights is inevitable. With reference to some case studies, the chapter will illustrate how courts have tried to resolve this conflict and also how reliance on legislation assisted communities in asserting their burial rights. Religious communities have a duty to educate and inform the court of their specific religious views or practices. Often there is a lack of understanding on the part of the courts, especially in relation to different, minority and traditional religions, and it has been stated that "[m]uch of the jurisprudence appears to be grounded in a worldview that separates land from religion, history from spirituality, and belief from practice" ${ }^{2}$

1 Associate Professor, Faculty of Law, Rhodes University, South Africa.

2 Ratipa MM. 2015. "'Just Piles of Rock to Developers but Places of Worship to Native Americans' - Exploring the Significance of Earth Jurisprudence for South 


\section{PROTECTING OUR RELIGIOUS AND CULTURAL HERITAGE: A LEGISLATIVE FRAMEWORK}

\section{The National Heritage Resources Act 25 of 1999 (NHRA)}

The South African Heritage Resources Agency (SAHRA) is the national administrative body responsible for the protection of South Africa's cultural heritage. It was established through the National Heritage Resources Act (NHRA). The legislation aims to promote good management of the national estate ${ }^{3}$ and to enable and encourage communities to nurture and conserve their legacy so that it may be bequeathed to future generations. According to the preamble:

Our heritage is unique and precious and it cannot be renewed. It helps us to define our cultural identity and therefore lies at the heart of our spiritual well-being and has the power to build our nation. It has the potential to affirm our diverse cultures, and in so doing shape our national character. Our heritage celebrates our achievements and contributes to redressing past inequities. It educates, it deepens our understanding of society and encourages us to empathise with the experience of others. It facilitates healing and material and symbolic restitution and it promotes new and previously neglected research into our rich oral traditions and customs.

This quotation from the NHRA encapsulates the spirit of the SAHRA. In terms of the Act, "heritage resource" means any place or object of cultural significance. "Cultural significance" includes reference to spiritual value and according to Section 3(1) they are considered part of the national estate. The national estate also includes graves and burial grounds, including ancestral graves. ${ }^{4}$

A place or object will also be considered part of the national estate if it has cultural significance or other special value because of its strong or special association with a particular community or cultural group for social, cultural or spiritual reasons. ${ }^{5}$ In addition to the formal protection of culturally significant graves, all graves older than 60 years and not in a cemetery (such as ancestral graves in rural areas) are protected. The legislation protects the interests of communities which have an interest in the graves and require that they must be contacted and consulted before any disturbance can take place. Agreements must also be made with such communities and individuals regarding the future of such grave or burial ground. In this regard, Section 5 of the Act emphasises

African Cultural Communities", Potchefstroom Electronic Law Journal 18(1):3226.

3 Section 3(1) of the Act states that those heritage resources of South Africa that are of cultural significance or other special value for the present community and for future generations must be considered part of the national estate and fall within the sphere of operations of heritage resources authorities. Section 2 includes a list of such resources, including graves and burial sites.

$4 \quad$ NHRA, s 3(2)(g).

5 NHRA, s 3(3)(g). 
the fact that heritage resources form an important part of the history and beliefs of communities and must be managed in a way that acknowledges the right of affected communities to be consulted and to participate in their management.

Section 8 of the NHRA provides for a three-tier system for heritage resources management. National level functions are the responsibility of SAHRA, provincial level functions are the responsibility of provincial heritage resources authorities and local level functions are the responsibility of local authorities. Heritage resources authorities and local authorities are accountable for their actions and decisions and the performance of functions under this system. ${ }^{6}$ In the examples discussed below, it will become clear that this three-tier system and the lack of communication and coordination between the different tiers are some of the main reasons for the poor implementation of the Act.

Heritage resources contribute significantly to research, education and tourism and according to the World Tourism Organization (UNWTO), the United Nations agency responsible for the promotion of responsible, sustainable and universally accessible tourism. Approximately 300 to 330 million tourists visit the world's key religious sites every year, including burial sites. ${ }^{7}$ UNWTO Secretary-General, Teleb Rifai views religious tourism as crucial in building cultural dialogue and peace. According to Rifai, "Religious tourism can also be a powerful instrument for raising awareness regarding the importance of safeguarding one's heritage and that of humanity, and help preserve these important sites for future generations." 8

South Africa has many sacred sites, as many as there are cultures and beliefs, ranging from sacred hills, valleys and lakes to mosques, kramats - the holy shrines of Islam - and Hindu temples. These religious heritage sites provide important meeting grounds for both visitors and communities. They can drive economic growth and international tourism, but more importantly they contribute and develop tolerance, respect and mutual understanding between different cultures and religions. There are more than twenty recognised kramats in the Cape Peninsula area, with one of the oldest known gravesites in Constantia. ${ }^{9}$ These kramats mark the graves of Holy Men of the Muslim faith who have died at the Cape. Some of the top religious sites in South Africa, according to the travel website Trip Advisor, are the Hare Krishna Temple of Understanding in Durban, St George's Cathedral in Cape Town Central, the Dutch Reformed Church in Stellenbosch, Regina Mundi in Soweto, Nizamiye

6 NHRA, s 8(1).

7 Press Release. 2014. "Tourism can protect and promote religious heritage", 10 December. Online at: http://media.unwto.org/press-release/2014-12-10/tourismcan-protect-and-promote-religious-heritage

8 Ibid.

9 Collingridge Lee-Anne. 2015. “The Cape's kramats: A unique religious and cultural heritage", 8 September. Online at: http://www.southafrica.net/blog/en/posts/entry/ the-capes-kramats-a-unique-religious-and-cultural-heritage 
Mosque in Midrand and the Cathedral of St Michael and St George in Grahamstown. ${ }^{10}$

Heritage resources have the capacity to promote reconciliation, understanding and respect, and contribute to the development of a unifying South African identity. They provide evidence of the origins of South Africa and must be carefully managed, although the challenges outlined below will illustrate that it is indeed not always the case. The NHRA also provides that laws and procedures must be clear and give content to the fundamental rights set out in the Constitution. What follows is a brief outline of the most important constitutional mechanism in place for the protection of the religious rights and heritage of communities in South Africa, followed by specific examples and case studies illustrating some challenges in the legislative content and application experienced by communities.

\section{Constitutional protection}

Section 15 of the Constitution of the Republic of South Africa, 1996, ${ }^{11}$ provides that everyone has the right to freedom of conscience, religion, thought, belief and opinion. Freedom of religion includes traditional African religions and practices, and this is also reflected in numerous international documents. ${ }^{12}$ However, individuals and community may not exercise the right in a manner inconsistent with the other provisions of the Bill of Rights.

Section 31 of the South African Constitution further provides that persons belonging to cultural, religious or linguistic communities may not be denied the right, with other members of that community, to enjoy their culture, practice their religion and use their language, and to form, join or maintain cultural, religious and linguistic associations and other organs of civil society, including therefore indigenous communities. Section 31 of the Constitution reflects Section 27 of the International Convention on Civil and Political Rights (ICCPR) to which South Africa is a party. ${ }^{13}$ This section is very important in relation to religious and cultural heritage, since the traditions and culture of indigenous

10 Trip advisor. 2016. "Religious Sites in South Africa", November. Online at: https:// www.tripadvisor.co.za/Attractions-g293740-Activities-c47-t10-South_Africa.html

11 Constitution of the Republic of South Africa, 1996.

12 Article 18 of both the Universal Declaration of Human Rights, G.A. res. 217A (III), U.N. Doc A/810 at 71 (1948) and the International Covenant on Civil and Political Rights, G.A. res. 2200A (XXI), 21 U.N. GAOR Supp. (No. 16) at 52, U.N. Doc. A/6316 (1966), 999 U.N.T.S. 171, entered into force Mar. 23, 1976; article 9 of the Convention for the Protection of Human Rights and Fundamental Freedoms, 213 U.N.T.S. 222, entered into force Sep. 3, 1953, as amended by Protocols Nos 3, 5, 8, and 11, entered into force Sep. 21, 1970, Dec. 20, 1971, Jan. 1, 1990, and Nov. 1, 1998 respectively; article 1 of the Declaration on the Elimination of All Forms of Intolerance and of Discrimination Based on Religion or Belief, G.A. res. 36/55, 36 U.N. GAOR Supp. (No. 51) at 171, U.N. Doc. A/36/684 (1981).

13 "In those States in which ethnic, religious or linguistic minorities exist, persons belonging to such minorities shall not be denied the right, in community with the 
communities are often influenced by spiritual beliefs and these communities have strong spiritual connections to their lands.

Section 9 of the Constitution further provides for the right to equality before the law and the right to equal protection and benefit of the law, non-discrimination on various grounds, including ethnic or social origin and culture. In order to give effect to Section 9(4) of the Constitution, the South African Parliament passed the Promotion of Equality and Prevention of Unfair Discrimination Act of 2000. Indigenous people and communities may therefore not be discriminated against on basis of race, culture, religion or any of the grounds envisaged in Section 9(3) of the Constitution. Various other provisions of the Constitution relate to religion and religious freedom. Sections 185 and 186 respectively provide for a Commission for the Promotion and Protection of the Rights of Cultural, Religious and Linguistic Communities (CRL Commission). Various other human rights such as the right to human dignity, the right to freedom of expression, and the right to freedom of association, relate indirectly to the protection of religious freedom.

Section 7(2) of the Constitution further makes it clear that the state must not only respect and protect the rights in the Bill of Rights, but also promote and fulfil them. It further emphasises the relevance of customary law, in that the Bill of Rights does not deny the existence of any other rights or freedoms that are recognised or conferred by common law, customary law or legislation, to the extent that they are consistent with the Bill. ${ }^{14}$ When interpreting the Bill of Rights, a court must also promote the values that underlie an open and democratic society based on human dignity, equality and freedom and must consider international law. ${ }^{15}$ In this regard, the International Labour Organization (ILO) Convention 169 is relevant. Although South Africa is not a signatory to this Convention, it provides relevant guidelines and has persuasive value when a dispute of this nature must be resolved by the courts. ILO Convention 169 is the Indigenous and Tribal Peoples Convention of 1989 (ITP Convention). ${ }^{16}$ The ITP Convention is based on respect for the cultures and ways of life of indigenous and tribal peoples. It aims at overcoming discriminatory practices affecting these peoples and enabling them to participate in decision making that affects their lives.

The ITP Convention acknowledges the fact that in many parts of the world indigenous people are unable to enjoy their fundamental human rights to the same degree as the rest of the population of the states within which they live, and that their laws, values, customs and perspectives have often been eroded.

other members of their group, to enjoy their own culture, to profess and practise their own religion, or to use their own language."

14 Constitution of the Republic of South Africa, 1996, s 39(3).

15 Constitution of the Republic of South Africa, 1996, s 39(1).

16 ILO Convention 169 - Indigenous and Tribal Peoples Convention, 1989 (No. 169). Convention concerning Indigenous and Tribal Peoples in Independent Countries, entered into force Sep. 5, 1991. Adoption: Geneva, 76th ILC session (27 June 1989). 
The Preamble specifically recognises "the aspirations of these peoples to exercise control over their own institutions, ways of life and economic development and to maintain and develop their identities, languages and religions, within the framework of the States in which they live." Article 14.2 of the Convention gives due and full recognition to "the right of the [indigenous] people to use lands not exclusively occupied by them, but to which they have traditionally had access for their subsistence and traditional activities". Similar sentiments are echoed in Article 26 of the United Nations Declaration on the Rights of Indigenous Peoples (UNDRIP), which provides that:

Indigenous peoples have the right to own, develop, control and use the lands and territories, including the total environment of the lands ... which they have traditionally owned or otherwise occupied or used. This includes the right to the full recognition of their laws, traditions and customs, land tenure systems and institutions for the development and management of resources, and the right to effective measures by States to prevent any interference with, alienation of or encroachment upon these rights.

UNDRIP was adopted through resolution 61/295 of the General Assembly. While as a General Assembly declaration UNDRIP is not a legally binding instrument under international law, it "represents a commitment on the part of the United Nations and Member States to its provisions, within the framework of the obligations established by the Charter of the United Nations." ${ }^{17}$ UNDRIP elaborates on existing human rights standards:

The Declaration does not attempt to bestow indigenous peoples with a set of special or new human rights, but rather provides a contextualized elaboration of general human rights principles and rights as they relate to the specific historical, cultural and social circumstances of indigenous peoples. The standards affirmed in the Declaration share an essentially remedial character, seeking to redress the systemic obstacles and discrimination that indigenous peoples have faced in their enjoyment of basic human rights. From this perspective, the standards of the Declaration connect to existing State obligations under other human rights instruments. ${ }^{18}$

UNDRIP contains further provisions which traditional communities can refer to in their mission to protect their cultural sites. Article 25 emphasises the rights of indigenous peoples to "maintain and strengthen their distinctive spiritual and material relationships with the lands they have traditionally owned or otherwise occupied or used, and to uphold their responsibilities to future generations". Article 29 further provides for the right to the conservation

17 The United Nations Declaration on the Rights of Indigenous Peoples: A Manual for National Human Rights Institutions. 2013. The Office of the United Nations High Commissioner for Human Rights, August, 37. Online at: http://www.ohchr.org/ Documents/Issues/IPeoples/UNDRIPManualForNHRIs.pdf

Ibid. 
and protection of the environment and the productive capacity of their lands or territories and resources. Re-enforcing the values expressed in the NHRA, it provides for private access to religious and cultural sites ${ }^{19}$ and the right to maintain, control, protect and develop their cultural heritage. ${ }^{20}$

Section 234 of the Constitution of the Republic of South Africa, 1996, provides that "in order to deepen the culture of democracy established by the Constitution, Parliament may adopt Charters of Rights consistent with the provisions of the Constitution". Any such charter of rights will then have the force of law. The Constitution envisages that the rights in the Constitution may be further extended, supplemented and given content by way of such additional charters.

The South African Charter of Religious Rights and Freedoms (SACRRF) is a document that defines the freedoms, rights, responsibilities and relationship between the "State" of South Africa and her citizens concerning religious belief. $^{21}$ The Charter expresses what freedom of religion means to those of religious belief and religious organisations within a South African context and the daily rights, responsibilities and freedoms that are associated with this right. These include the right to gather to observe religious belief, freedom of expression regarding religion, the right of citizens to make choices according to their convictions, the right to change their faith, the right to be educated in their religion, the right to educate their children in accordance with their philosophical and religious convictions and the right to refuse to perform certain duties or assist in activities that violate their religious beliefs.

The SACRRF was first signed at a public ceremony in Johannesburg on 21 October 2010, and signatories continue to be added to the open document. Signatories include religious groups and organisations, human rights organisations, legal and academic entities and media bodies. If passed into law, the Charter will ensure that the rights of religious believers are clearly defined and protected under the law of South Africa. The SACRRF may be used as a legal instrument even as the current climate of understanding and tolerance between government and religion may alter. After the public signing of the SACRRF, a Council for the Protection and Promotion of Religious Rights and Freedoms was established to oversee the process of the Charter being formally enacted into South African law. The passing of the SACRRF into law will mean that religious believers have legal impartiality and protection to practice all elements of religious belief under the Constitution. The SACRRF is the first public charter to be developed under Section 234 of the Constitution of South Africa. ${ }^{22}$

19 UNDRIP, art 12.

20 UNDRIP, art 31(1).

21 The South African Charter of Religious Rights and Freedoms. 2016. “Explanatory notes on the Charter", 16 May, 4. Online at: http://www.crlcommission.org.za/docs/ sacrrf.pdf

22 See further Charter, 4-5. 
The SACRRF makes provision for the right of every person to have access to sacred places and burial sites relevant to their convictions. Such access and the preservation of such places and sites must be regulated within the law and with due regard for property rights. According to the Charter:

4. Subject to the duty of reasonable accommodation and the need to provide essential services, every person has the right to the private or public, and individual or joint, observance or exercise of their convictions, which may include but are not limited to reading and discussion of sacred texts, confession, proclamation, worship, prayer, witness, arrangements, attire, appearance, diet, customs, rituals and pilgrimages, and the observance of religious and other sacred days of rest, festivals and ceremonies.

4.1. Every person has the right to private access to sacred places and burial sites relevant to their convictions. Such access, and then preservation of such places and sites, must be regulated within the law and with due regard for property rights.

In accordance with Section 4 of the Charter, anyone is entitled to visit sacred places and burial sites, as long as property rights and other legal considerations are observed. Importantly, any visit to sites on private land must be arranged with the landowner, and may not put an unreasonable burden on the landowner or cause damage of any kind to the property. Emphasis is placed on mutual respect and consideration. ${ }^{23}$ Sacred places and burial sites are found on both public and private land and challenges are experienced by communities in relation to both. With reference to some practical examples, the chapter will now highlight some challenges faced by communities specifically in relation to the reuse and relocation of graves.

\section{CHALLENGES}

\section{The reuse of graves}

In accordance with Section 156(1) of the Constitution of the Republic of South Africa, 1996, a municipality has executive authority in respect of and has the right to administer all the local government matters listed in Part B of Schedule 4 and Part B of Schedule 5 of the Constitution. These are functional areas (for instance education or health services) in which the national, provincial or local government have legislative competence in. Municipalities also have the right to administer any other matter assigned to them by national or provincial legislation and further may make and administer by-laws for the effective administration of the matters that they have the right to administer. Part B of Schedule 5 specifically provides for cemeteries, funeral parlours and

23 See Charter, 29. 
crematoria. The NHRA supports this section of the Constitution by specifying that local government is responsible for the execution of the NHRA at local level. Municipalities are responsible for declaring which heritage resources have cultural significance at local level. According to the NHRA, the national system for the management of heritage resources applies to a local authority, as well. ${ }^{24}$ In terms of making by-laws, the NHRA provides that a local authority may, with the approval of the provincial heritage resources authority, make by-laws in order to regulate the admission of the public to any place protected under the NHRA to which the public is allowed access. The by-laws may also regulate the conditions of use of any place protected under the NHRA which is under its control and the protection and management of a protected area. ${ }^{25}$

In relation to burial grounds and graves, the NHRA does make provision for the fact that where it is not the responsibility of any other authority, SAHRA must conserve and generally care for burial grounds and graves protected. ${ }^{26}$ The NHRA, however, follows the principle that heritage resources should be managed by the levels of government closest to the community and therefore these local and provincial authorities should manage heritage resources as part of their planning process.

Recently, a grave fight with Eskom, South Africa's main electricity provider, erupted over burial sites at the R145-billion Medupi power plant, which may have been built on graves of the ancestors belonging to at least 14 families. These families are fighting for the right to visit these graves and allege that they were not properly consulted about the development when construction for the multibillion rand project began more than seven years ago. According to a report by the African Development Bank, "no real effort has been made to identify such unmarked graves and so the risk of desecration remains substantial." ${ }^{27}$ In African religious belief systems, it is important to have access to graves as it is custom to visit the sites and perform rituals when people face problems. ${ }^{28}$ Many traditional religious communities in South Africa see the world of the ancestors as "analogous" and "contiguous" to the world of the

24 NHRA, s 4(a).

25 NHRA, s 54(1).

26 NHRA, s 36(1).

27 Ackroyd Bianca. 2014. "EXCLUSIVE: Grave fight with Eskom over burial sites at Medupi", 4 August. Online at: https://www.enca.com/families-fight-eskom-overaccess-graves-medupi

28 Mndende N. 2013. "Law and religion in South Africa: An African traditional perspective", NGTT 54(4):75. According to Mndende, African tradition religion means the "indigenous religion of the Africans. It is the religion that has been handed down from generation to generation by the forebears of the present generation of Africans. It is not a fossil religion (a thing of the past) but a religion that Africans today have made theirs by living it and practising it". See further Dopamu PA. 1991. "Towards understanding African Traditional Religion", in Uka EM (ed). Readings in African Traditional Religion. New York: Peter Lang, 19-37. 
living. ${ }^{29}$ They also believe that the improper care of the dead has more sinister and far-reaching consequences for the community at large. ${ }^{30}$ Communities perform rituals for various purposes. These rituals are extraordinary practices performed by the living for the spiritual world, and include special gatherings of the clans aimed at communal religious practices, like the rites of passage and sometimes "special rituals as requested by ancestors, like the bringing back of the spirit of some family member who died far away from home. In these religious gatherings the community acts out its various forms of worship. Through these rituals, unity and healing are achieved." 11

The Commission for the Promotion and Protection of the Cultural, Religious and Linguistic Rights of Communities (CRL Commission) has also received numerous complaints in relation to the reuse of graves. In September 2015, the eThekwini Municipality called on the public to claim all unclaimed family graves, by renewing grave leases to ensure graves more than 10 years old were legally leased. According to eThekwini cemetery by-laws, the city may reuse graves which are more than 10 years old, where leases have not been renewed, after advertising its intention to allow interested lessees to apply for renewals. Religious and traditional leaders were shocked at the call to claim graves for recycling. According to the chairman of the KZN House of Traditional Leaders, Zulu culture did not allow the practice: "In our culture, we respect graves. Once a person has passed away, we respect that person and we can't do anything to remove the grave except to discuss with the family." ${ }^{32}$

According to the Anglican Bishop of KwaZulu-Natal, "For people of all faiths, death isn't burying someone and then forgetting about them. It is much deeper than that and for most faiths there is still a connection." 33 Early this year, the CRL Commission, during an investigation into religious and cultural leaders and practices, also investigated the policy and practices of the eThekwini Municipality in relation to the reuse of graves. The CRL Commission embarked upon a study on "Reuse of Graves by Local Governments: A Solution or Violation of Cultural and Religious Rights of Communities", after receiving a

29 See further Ngubane H. 1976. "Some notions of 'purity' and 'impurity' amongst the Zulu", African Journal of the International African Institute 46(3):274-284.

30 Saccaggi B and Esterhuysen A. 2014. "Sekuruwe grave relocation: a lesson in process and practice", The South African Archaeological Bulletin 69(200):176.

31 Mndende, "Law and religion", 78. For further readings on this topic, please see Mndende N. 2006. African Spiritual Journey: Rites of Passage among the Xhosa speaking of South Africa. Cape Town: Icamagu Institute; Mndende N. 2009. Tears of Distress: Voices of a denied spirituality in a democratic South Africa. Idutywa: Icamagu Institute; Mbiti S. 2015. Introduction to African Religion. Second Edition. Long Grove, IL: Waveland.

32 Comins Lyse. 2015. "Durban's plan to recycle graves", 14 September. Online at: http://www.iol.co.za/news/south-africa/kwazulu-natal/durbans-plan-to-recyclegraves-1915860

Ibid. 
number of complaints from the public, particularly from the eThekwini Metro Municipal area. According to the Mayor of eThekwini:

... dealing with the issue of cemetery space was difficult because cemeteries are competing with developments such as housing, agriculture and infrastructure. It is really a competition between the dead and the living. As Government we have a responsibility to provide housing and other development infrastructure for our people to ensure that we have a sustainable City. On the other hand we have to meet the demand for cemeteries, as we are finding that some of our communities are still sceptical about alternative burial methods that have been identified. ${ }^{34}$

It is clear that municipalities are facing numerous challenges in finding new burial spaces, but the practice of reusing graves is also violating the cultural and religious rights of people. ${ }^{35}$ The CRL Commission was informed that local governments' disregard for the principles regarding religious and cultural rights of most communities, have led them to feel that the practice reuse of graves without their consent, is a violation of their religious and cultural rights. ${ }^{36}$

The South African Local Government Association (SALGA) acknowledged that the demand for land for cemeteries is high and recognised that cultural and religious beliefs attached to cemeteries and burial methods of communities cannot be undermined. However, they have made it clear in a statement that:

SALGA believes that municipalities are within their own right to exercise their bylaws in line with available legislation and thus alternative burial methods, including multiple internments, are legal as provided for in the legislation. ${ }^{37}$

Some of the solutions and alternatives to conventional burial proposed by SALGA include the use of eco-cemetery concepts, intensive recycling of graves, multiple-use approach to cemeteries and the employing a variety of costeffective methods as alternatives to traditional/in-ground burial, including cremations. ${ }^{38}$ According to African Traditional Religion, "a corpse cannot be kept in the homestead, whether it is in the form of bones or ashes; that is

34 CRL report, "Reuse of graves by local governments: A solution or violation of cultural and religious rights of communities". Report compiled by the Commission for the Promotion and Protection of the Cultural, Religious and Linguistic Communities, 18. Online at: http://crlcommission.org.za/docs/reusereport.pdf

35 Nxumalo Mphathi. 2016. "Reused graves issue could go to court", 3 February. Online at: http://www.iol.co.za/news/politics/reused-graves-issue-could-go-tocourt-1979455

36 CRL report, 3.

37 Press release. 2015. "Reuse of graves by local governments: a solution or violation of cultural and religious rights of communities". Issued by the South African Local Government Association (SALGA), 3 June. Online at: https://www.facebook. com/permalink.php?id=165498883507659\&story_fbid=916054318452108

38 CRL report, 19. 
regarded as isimnyama (being under dark cloud). Cremation is out, no one can keep ashes at home, neither to sprinkle it in the sea or river; that is out of the question. A deceased individual should be in a grave." ${ }^{\prime 39}$

A lot of the problems that communities have experienced seems to be traced back to poor communication, lack of consultation with communities and various stakeholders and poor implementation of the NHRA and other relevant legislation. Section 5 of the NHRA emphasises the fact that heritage resources form an important part of the history and beliefs of communities and must be managed in a way that acknowledges the right of affected communities to be consulted and to participate in their management. This is no easy task and SAHRA recently briefed the parliamentary Tourism Portfolio Committee on the importance of heritage sites in tourism development. ${ }^{40}$ The Tourism Portfolio Committee is responsible for the oversight of the Department of Tourism. According to SARHA, they face numerous challenges, including striking a balance between heritage conservation and development of land and the lack of skills and resources in the heritage management sector. SAHRA is further challenged by limited capacity in its core business and provincial heritage resources authorities that are non-functional. The geographical spread of heritage resources nationally makes it very difficult to manage, and numerous of South Africa's heritage sites are in disrepair and need urgent upkeep and maintenance. In this regard funding and cooperation from government departments are lacking.

As outlined above, Section 8 of the NHRA provides for a three-tier system for heritage resources management. One of the challenges faced by SAHRA is the lack of cooperation between the different government spheres and perhaps legislation is needed to compel provinces and local governments to work more closely with the SAHRA. Esterhuysen is of the view that the tiered heritage system is "undeveloped, under-resourced and uncoordinated' and that the communication between the different heritage departments, agencies and councils, and the department of health, environment, and planning at the various government levels, result in 'slow and questionable decision making." ${ }^{41}$ Concerns were also raised in connection with this system of collaboration, insofar as it might not be the best thing for SAHRA to hand over a heritage site to a provincial or local authority. The parliamentary Tourism Portfolio Committee is of the view that when a site has been handed over to a province or a municipality, the SAHRA should still have responsibility. ${ }^{42}$ It has further been argued that the split in functions can be confusing as the communication

39 Mndende, “Law and religion”, 80.

40 Presentation by SAHRA to the Portfolio Committee on Tourism. 2015. "Importance of Heritage Sites in Tourism Development", Parliament, 4 September. Online at: https://pmg.org.za/committee-meeting/21461/

41 Esterhuysen A. 2009. "Undermining Heritage". The South African Archaeological Bulletin 64(189):1.

42 SAHRA, "Importance of Heritage Sites in Tourism Development". 
between authorities can be unreliable and it has the potential for applications or complaints to go missing. ${ }^{43}$

In relation to the relocation of human remains, it is argued that different arms of government (i.e. municipalities as well as provincial health departments) are applying the regulations, with no formal obligation on administrators to crosscheck information with another. It is further argued that "it appears that no one from these departments carries out on-site inspections to check that exhumations are carried out. ${ }^{44}$ Often administrators in the various heritage agencies and provincial and municipal departments of health, environment and planning work in isolation and are ignorant of the law. A lack of communication and proper consultation was a repeated theme in many of these cases. Communities are not aware of or not informed about the legislation. Communities are often not kept in the loop in relation to the status of the graves or about the processes involved where graves are in the process of being relocated and it is confirmed yet again that "heritage and social assessments and consultation process are carried out independently form one another" ${ }^{45}$ Provisions in the NHRA are also not complied with. There seems to the practice that heritage consultants work independently of communities, however, Section 38(3)(e) of the NHRA places an obligation on the responsible heritage resources authority to make sure that the report contains information about the results of consultation with communities affected by the proposed development and other interested parties regarding the impact of the development on heritage resources.

The CRL Commission remains of the view that the reuse of graves remains a disrespectful way of trying to solve the problem of development.They propose that national legislation that deals with the issue of the reuse of graves must be promulgated by parliament with immediate effect and that local governments should stop this practice of reusing graves. This has been acknowledged by SALGA who stated that they will "continue to facilitate engagements with the CRL Commission as well as other affected stakeholders to explore amicable solutions to the land issues in metropolitan municipalities." ${ }^{46}$

Cultural communities are often deeply connected to certain places in the natural world. These religious or sacred sites often carry with them "a whole range of rules and regulations regarding people's behaviour in relation to a set of beliefs to do with the spirits of the ancestors, as well as of more remote and powerful gods or spirits. ${ }^{47}$ Sacred sites form part of a community's cultural and religious heritage. The previous discussion has mainly focused on challenges experienced by communities in relation to burial and sacred sites on public land or where

43 Saccaggi and Esterhuysen, 174.

44 Saccaggi and Esterhuysen, 179.

45 Saccaggi and Esterhuysen, 180.

46 See SALGA statement.

47 Ratipa, “Just Piles of Rock", 3198-3199. 
conflict has arisen over these sites with public authorities. However, in terms of the constitutional protection of the religious rights and heritage of communities in South Africa, another land issue that religious and cultural communities face is the right to visit sacred places and burial sites situated on private land as well as the right to bury on these lands. This challenge brings two competing fundamental rights - the right to freedom of religion (Section 15) and the property clause (Section 25) in direct conflict with each other. With reference to some case studies, the next section will illustrate how courts have attempted to resolve this conflict but also how communities have managed to rely on the existing legislation in order to assert their burial rights on private land.

\section{The right to bury}

In South Africa, both the land owners and occupiers are protected by Section 25 of the Constitution. Under Section 25(9) of the Constitution, an Extension of Security of Tenure Act 62 of 1997 (ESTA) was promulgated in order to specify and regulate the rights and duties of occupiers and land owners. The right to bury on farmland has often proved to be problematic. On the one hand, landowners feel that they have a right to enjoy undisturbed use and ownership of their land. On the other hand, occupiers feel that as occupiers of land they have a right of security of tenure including the right to bury their deceased family members on land where they reside.

The case of Nkosi and Another v. Bührmann ${ }^{48}$ raised a sensitive and emotionally contentious question involving, on the one hand, the right to religious freedom, and particularly the right to practise one's religion, and, on the other hand, the right not to be deprived of one's land except by law. The appellant, Grace Nkosi wished to have the body of her late son, Petros Nkosi, buried on a farm in the Ermelo district where she resided as an occupier. The respondent, who is the owner of the farm, refused consent for the burial. In relation to the right to freedom of religion, the appellants relied heavily on Section 5 of ESTA, ${ }^{49}$ more particularly Section $5(\mathrm{~d})$ that provides that an occupier shall have the right to freedom of religion, belief and opinion and of expression. This clause is similar

48 Nkosi and Another v. Bührmann 20021 SA 372 (SCA).

49 "5. Fundamental rights. -

Subject to limitations which are reasonable and justifiable in an open and democratic society based on human dignity, equality and freedom, an occupier, an owner and a person in charge shall have the right to -

(a) human dignity;

(b) freedom and security of the person;

(c) privacy;

(d) freedom of religion, belief and opinion and of expression;

(e) freedom of association; and

(f) freedom of movement,

with due regard to the objects of the Constitution and this Act." 
to Section 15 of the Constitution, which guarantees that that everyone has the right to freedom of conscience, religion, thought, belief and opinion.

The appellant argued that central to her religious practice are the rituals of burying the dead, and that because the land they occupy is the only resource by means of which they can exercise their religious right and manifest its practice, such right must include the right to bury their dead on that land. To that right, therefore, the right of ownership has to yield. ${ }^{50}$ With reference to various cases, the court undertook an interpretative exercise by starting with a discussion of the ESTA Section5(d) right to religious freedom. ${ }^{51}$ The main question that they had to address in relation to the right to freedom of religion was whether the right to freedom of religion entitled the appellant by law to take some of the respondent's land for a grave. The court acknowledged that funeral and graveside rites, rituals and ceremonies are very much part of religious beliefs and practice $^{52}$ and that it is the right of all citizens to observe and carry out their religious practices when burying their dead. ${ }^{53}$ According to the facts in that case, the appellant did not claim that funeral and graveside rituals could not be observed in the case of a burial elsewhere. According to the court:

In those circumstances it cannot be said, without more, that the appellant's constitutional rights to practise her religious and cultural beliefs (that are protected by s 15 and s 31) will be denied to her if the burial is not permitted. That does not exclude the possibility, however, that where religious or cultural beliefs are so inherently attached to particular land that the right to hold and practise them would be denied if the rights of ownership are asserted, the latter rights might be equired to give way. That does not arise in the present case. ${ }^{54}$

The court highlighted the fact that a burial not only requires a piece of ground to be available, but also the necessary permission or consent of the land owner, whether the state, a juristic person or an individual..$^{55}$ The court came to the conclusion that the right to freedom of religion and religious practice has internal limits. "It does not confer unfettered liberty to choose a grave site nor does it include the right to take a grave site without the consent of the owner of the land concerned. It follows that s 5(d) of the Act does not, when viewed in isolation, confer the right which the appellant claims." ${ }^{156}$ The court subsequently dismissed the appeal.

When the judgment in the Nkosi case was given, Section $6(2)(\mathrm{dA})$ was not yet part of ESTA. As a result of this judgment, the legislature enacted Section 6(2)dA). In terms of Section $6(2)(\mathrm{dA})$ of ESTA, an occupier shall have the right to bury

50 Nkosi, para 32.

51 Nkosi, para 41-44.

52 Nkosi, para 46.

53 Nkosi, para 47.

54 Nkosi, para 46.

55 Nkosi, para 47.

56 Nkosi, para 49. 
a deceased member of his or her family who at the time of that person's death, was residing on the land on which the occupier is residing, in accordance with their religion or cultural belief, if an established practice in respect of the land exists. In order to enjoy this protection, the occupier must thus establish on the balance of probabilities that:

- he or she is an 'occupier' on the farm where he or she intends burying the deceased on;

- the deceased was a member of his or her family;

- the burial sought would be in accordance with his or her religious and/or cultural beliefs;

- the deceased was residing on land, which the occupier resided at the time of death of the deceased; and

- an established practice on land exists to bury deceased family members.

"Established practice" in terms of ESTA means a practice by which the owner or person in charge or his or her predecessor in title routinely gave permission to people residing on the land to bury deceased members of their family on that land in accordance with their religion or cultural belief.

In the case of Nhlabathi, ${ }^{57}$ the family of Kiti Elijah Nhlabathi approached the Land Claims Court (LCC) for an order permitting his burial in the Nhlabathi graveyard on the farm Mooifontein. The deceased had been living in the same household with the applicants on the farm. The Nhlabathi family informed the owner of the farm of the death of the deceased and requested permission for his remains to be buried on the farm. The owner firmly rejected the request. The Nhlabathi family then approached the LCC and relied on Section 6(2)(dA) of ESTA. The court ordered that the family is entitled, in terms of Section 6(2) (dA) of ESTA to bury the body of Kiti Elijah Nhlabathi on the farm Mooifontein. The court was happy to conclude that nothing was put before them to substantiate a submission that the proprietary rights of the owner in this case might outbalance the burial rights of the first applicant and that at the time of his death, the deceased was residing on Mooifontein. In the court's view, there existed an established practice to permit the burial of deceased occupiers and members of their families on the farm Mooifontein.The applicants belonged to the Christian Church in Zion. The burial would be conducted in accordance with the rites of that church, just as the burials of the two Nhlabathi children, Zandile and Albert.

In Dlamini and Another v. Joosten and Others ${ }^{58}$ the family of Gertrude Ntombi Zondia approached the LCC for an urgent order in that they be permitted to bury the deceased at the Dlamini family burial site on the farm Bockenhoud 
Fontein, a farm owned by the Joosten family. In the LCC, Bam JP refused to permit the burial, but granted leave to appeal against its decision to the Supreme Court of Appeal (SCA). The Dlamini family has resided and worked on the farm for generations, and over the years they had buried their deceased on the farm in accordance with their religion and cultural belief with the consent of the Joostens. However, in 2002 the Joosten family withdrew the permission, and when the Dlaminis sought permission from the Joostens to bury the deceased, this was refused. The Dlaminis submitted that it is a religious or cultural belief that deceased members of their family must be buried close to their homestead so that the spirits of their ancestors might be close to them. According to them, "It was and is extremely important to my late wife and I that we were entitled to bury our deceased family members near our home on the farm, as it is a cultural imperative for us that our ancestors and our family members are buried close to our home." 59

The Dlamini's based their cause of action on Section 6(2)(dA) of ESTA, which permits a person who occupies land that belongs to another person to bury deceased members of his or her family on that land if permission for burials had routinely been given in the past. They argued successfully that once a practice of allowing burials had been established on the farm, as it had been in the case of the deceased, it could not be withdrawn unilaterally. The SCA upheld the appeal.

\section{CONCLUSION}

The chapter has sought to give an overview of some of the legal mechanisms in place to protect and promote communities' religious rights, particularly in relation to burial places. Various factors may have an influence when local communities are involved in disputes relating to their sacred sites. Some of these factors highlighted in this chapter included a lack of communication and engagement with communities and also ignorance of the laws, procedures and practices that are available to communities in order to assert their religious rights. It has been noted that certain stakeholder groups such as the poor, women and the youth are not effectively engaged in cases affecting burial rights, often due to a lack of financial resources to attend public meetings or a lack of access to newspapers in which notices are published. Often there are also language barriers when it comes to notices and communications, Concerns can also not be adequately understood or addressed. ${ }^{60}$ In cases where there is a plan to reuse a grave, the CRL Commission proposes that local governments should ask all affected family members to decide which members should be buried together in one grave. Local governments should also appropriately and effectively engage in discussions with all affected communities before closing

59 Dlamini, para 21.

60 Saccaggi and Esterhuysen, 179. 
down cemeteries or reusing graves in their areas. ${ }^{61}$ Direction can also be taken from the Regulations on fair administrative procedures, made in terms of Section 10 of the Promotion of Administrative Justice Act 3 of 2000. In relation to public hearings in a community consisting of a considerable proportion of people who cannot read or write or who otherwise need special assistance, an administrator must notify people in that area in a manner and language that will bring the matter to the attention of the community at large, such as group meetings, surveys, the Internet, radio or television broadcasts, posters or leaflets and secretarial assistance to persons. When communities are involved in a dispute, the way in which an argument is formulated and presented to court can also make or break a case. It is essential that communities themselves have input into the process. The various case studies in relation to the ESTA Act have illustrated that communities can be successful in asserting their religious rights where they construct good religious arguments in terms of the applicable laws.

The SACRRF further plays an important role since it states specifically that religious institutions have the right to determine its own religious affairs and that the the state must create a positive and safe environment for the exercise of religious freedom. In approving a plan for the development of land, the state must also consider religious needs. ${ }^{62}$ Since the SACRRF provides for the right of communities to access sacred places and burial sites relevant to their convictions, they have to make sure that those involved clearly understand their views and convictions.

The right to freedom of religion provides religious communities with the opportunity, but also the responsibility, not only to give content to this right, but also to formulate and defend their own religious identity within the limitations set by the Constitution and the law. The NHRA provides that laws, procedures and administrative practices must be clear and generally available to those affected thereby. They must serve as regulatory measures but also provide guidance and information to those affected thereby. These laws and procedures must further give content to the fundamental rights set out in the Constitution, set out above. ${ }^{6}$ Communities should therefore explore all the possible avenues available to them. This include, but are not limited to the common law, national legislation, local government by-laws, customary law, constitutional provisions, international law and examples of cases decide by various courts.

Churches and religious institutions can also play a role in supporting their communities in preserving and protecting their heritage. Religion is a vital aspect of cultural heritage in South Africa for many individuals and groups. According to the National Heritage Council, "it is imperative that religious organisations (whether churches or traditional religious groups) as part of their

61 CRL report, 21.

62 The South African Charter of Religious Rights and Freedoms, s 3.1.

63 NHRA, s 5(3). 


\section{RELIGIOUS PLURALISM, HERITAGE AND SOCIAL DEVELOPMENT IN AFRICA}

obligations, position themselves as positive custodians of social and cultural values of the communities they serve." ${ }^{64}$

64 Mancotywa Sonwabile. 2014. “Critical Conversations about Heritage, Popularising Contemporary Heritage Issues. National Heritage Council of South Africa", 10. Online at: http://www.nhc.org.za/a-book-that-sparks-debate-about-contemporaryheritage-issues-launched/ 